\title{
Economic Value Added
}

\author{
Surtikanti \\ Departemen Akuntansi \\ Universitas Komputer Indonesia \\ Bandung, Indonesia \\ surtikanti@email.unikom.ac.id
}

\author{
Dean Subhan Saleh \\ Departemen Akuntansi \\ Sekolah Tinggi Ilmu Ekonomi Mutaqin \\ Purwakarta, Indonesia \\ subhan.indomin@gmail.com
}

\begin{abstract}
This study aims to analyze economic value added as a measure of the success of the company's management performance, what is the relation between the economic value added and the performance measurement of a company. The method of research is a descriptive method. Research data was obtained from the Indonesia Stock Exchange and the annual financial statements of sample companies that did not merge, analyze and experience changes in business groups by loading on the IDX.com web. Manufacturing companies are used in this study with 151 sample companies. The results of the study conclude that economic value added can measure management achievement based on the size of economic value added created by the company as a result of activities carried out during a certain period. Economic value added can be a measure of financial performance based on value by calculating capital costs for equity. The influence of economic value added in a company as a whole is very important so this should not be overlooked in the preparation of the company's strategy.
\end{abstract}

Keywords-Economic value added, value creation and capital costs

\section{INTRODUCTION}

Economic Value Added (EVA) is a financial performance measurement tool based on value to measure a company's financial performance by calculating capital costs for equity [1]. EVA is the most important innovation because it makes modern profit theory. The managerial implications of this theory are easily accessible to company managers who are not well trained in finance or never think about it. EVA helps managers to better understand financial goals, and thus help them to achieve their goals.

The results study show that EVA has a positive influence on the company's stock returns in LQ45. Fundamental analysis proves that the value of a stock is strongly influenced by the performance of the company that issued the shares. If the prospect of a company is predicted to rise, the company's stock price will increase [2].

Similar results are also corroborated by comparing the performance appraisal of a company based on the concept of EVA and ROA on stock returns, the result of which is a measurement based on EVA produces a small corre Portfolio investment strategy research using EVA, research shows that the portfolio formed by negative EVA results in a relatively high rate of return compared to companies that have positive EVA [4].

The event study methodology to investigate whether companies that adopted EVA Stern Stewart systems had poor performance, and whether using EVA adopted, the company would have a good performance. There is sufficient evidence to conclude that companies that have poor performance values suggest that companies adopt EVA, in other words adopting EVA can improve company performance. The results of this study state that the company has adopted EVA experiencing a relatively high increase in profitability compared to those who have not adopted EVA [5].

In this study will explain how economic value added as a measure of the success of the company's management performance and how the market reacts to the company's economic value added.

\section{METHOD}

The research method used by the writer in this study is descriptive method. The sample in this study were all manufacturing companies listed on the Indonesia Stock Exchange for the period 2005-2008, namely 151 manufacturing companies after being selected using purposive sampling with the following criteria:

a. The company issued financial statements after being audited during the period 2005-2008 with the opinion of Unqualified Opinion.

b. The company was not delisted during the observation period and issued financial statements as of December 31 for the period 2005 to 2008 .

c. The company does not make announcements of economic events other than financial statements, such as acquisitions or mergers, restructuring or changes in business groups.

d. The period of observation for four years is considered sufficiently representative of the stability of the condition of the Indonesia Stock Exchange.

e. The best EVA manufacturing company for assets of more than Rp. 1 Trillion and assets of less than Rp. 1 Trillion.

f. A stable manufacturing company distributed dividends during 2005 to 2008.lation when compared with ROA [3].

This study uses secondary data in the form of annual report issuers of listed investment companies on the Indonesia Stock Exchange during the period 2005-2008 obtained from the Jakarta Stock Exchange (IDX) website at http://www.idx.co.id 


\section{RESULTS}

A. Value Added Economy as a Measure of Success in Company Management Performance

The concept of Economic Value Added (EVA) has the principle that management success is measured based on economic value added created during a certain period. The Value Added Assessment process is carried out to identify activities that are non-value added and added value. Furthermore, management strives to add activities that value added to stakeholders and reduce or eliminate activities that are non-value added.

EVA in terms of goal setting helps management to be guided by value building. Consistent with the principle of Net Present Value (NPV), EVA can be the basis for capital budgeting about the assessment of a project. Projects with positive discounted EVA will be accepted, and conversely projects with discounted negative EVA will be rejected. In terms of performance assessment, Economic Value Added becomes an important criterion for assessing management performance. Determination of the correct assessment criteria will affect the motivation and workings of management, all of which affect the payroll system or incentives in a company.

\section{B. Market Reaction to EVA Companies}

Every company wants the value of economic value added (EVA) to increase continuously, because economic value added (EVA) is a fundamental benchmark of the rate of return on capital.

The results of the study prove significantly that investors react to the issuance of financial statements in the event window period that has been predetermined to return to companies that have positive EVA or companies that have negative EVA. In this result it can be explained that the company can still provide a positive return even though the resulting value is not too large.

The results of the study explain that companies that produce positive EVA values can provide good news for investors as an added value to obtain the desired returns by investors, and vice versa in companies that have negative EVA values, in this study companies that have negative EVA values can also affect investors react to the issuance of financial statements.

\section{IV.DISCUSSION}

Overall from the results of this study support the research with the results of research that companies with negative EVA values can provide a positive return, indicating investors react around the date of issuance of financial statements on companies that have a positive EVA or companies that have EVA values [6].

The results of this study also prove that previous research concluded that EVA is an accurate tool in understanding investor expectations reflected in the company's stock price [7]. Who examined the Performance of Public Companies in Malaysia using EVA concluded that EVA has a closer relationship with stock returns compared to traditional accounting tools, namely EPS [8].

Where examined the relationship of capital structure with Economic Value Added (EVA) in order to assess banking performance concluded that from the EVA calculation results, each bank during the study period was known to increase from the first semester to the second semester. This is more because banks can maintain interest income so that even though capital costs also increase it does not affect the decline in EVA [9].

Examined the comparison of EVA and ROE correlation to LQ45 stock prices on the Jakarta Stock Exchange concluded that EVA has a more significant correlation to stock prices compared to ROE. Some sample companies belonging to the LQ45 have a fairly high ROE but it is a value destroyer company because it has a negative EVA value [10]. Examines the effect of traditional accounting and EVA approaches on stock returns on the banking sector companies on the JSX concluding that EVA is superior to the stock return of the banking sector compared to ROE and ROA. This is because these banks cannot cover their capital costs from year to year even though the NOPAT value is high [11].

\section{CONCLUSION}

The conclusion that can be drawn is that the company's goal of profit maximization must be changed to the maximization of value or value. The concept of Economic Value Added (EVA) has the principle that management success is measured based on economic value added created during a certain period. Value Added is an important criterion for assessing company management performance. Companies that have positive economic value (EVA) or companies that have negative economic value added (EVA) still make investors interested in the company.

\section{ACKNOWLEDGMENT}

Thank you for the support from Rektor UNIKOM who has facilitated the issuance of the proceeding.

\section{REFERENCE}

[1] Young, David S \& O'Byrne, Stephen F. "EVA and Value - Based Management (A Practical Guide to Implementation)". United States of America: McGraw-Hill, pp 17, 2001.

[2] Itawidya "Analysis of the relationship of the company's financial performance using EVA with stock returns", 2003

[3] Hartono, Jogiyanto dan Chendrawati, "ROA dan EVA: A Comparative Empirical Study", Gajah Mada International Journal of Bussines pp.45-54. 1 Mei 1999.

[4] Ivanov, Stoyu I., Leong, Kenneth and Zaima, Janis K. "An Empirical Examination of Negative Economic Value Added Firms". The International Journal of Business and Finance Research 8. 2014.

[5] dE Wet JHvH, "EVA versus Traditional Accounting Measures of Performance as Drivers of Shareholder Value - A Comparative Analysis". Meditari Accountancy Research Vol. 13 No.2, 2005. 
[6] Lisa Linawati Utomo, "Economic Value Added as a Measure of Success in Company Management Performance. Jakarta: Journal of Accounting and Finance Vol. 1, No.28-42, 2004.

[7] Prakasa Mulya Yoga. " Analysis of the Relationship between Economic Value Added (EVA) and Market Value Added (MVA) in Manufacturing Companies Registered on the Stock Exchange" 2007.

[8] Ismail Issham, "Performances of Public-Listed Companies in Malaysia : Using EVA". University Sains Malaysia, Penang, Malaysia, 2002.

[9] Anshari Baddarruzaman, "Analysis of the Relationship of Capital Structure with Economic Value Added (EVA) To Assess Banking Performance", 2005.

[10] J. Panggabean, Raja Lambas. "Comparative Analysis of EVA and ROE Correlation of LQ45 Share Prices on the Jakarta Stock Exchange". Journal of Management and Business Sriwijaya Vol.3 No.5, 2005

[11] Hakim, Rahman, "Comparison of Company Performance with EVA, ROA Method, and Their Effects on Stock Returns in Companies Incorporated in the LQ 45 Index on the Jakarta Stock Exchange". Undergraduate Thesis, Faculty of Economics, Indonesian Islamic University. 2006 